\title{
STRATEGI KEPALA SEKOLAH SATUAN PENDIDIKAN KERJASAMA (SPK) DALAM MENEGAKKAN MANAJEMEN BERBASIS SEKOLAH (MBS)
}

\author{
Julianti Hadi Purnami \\ julie_naryo@yahoo.com \\ Hotner Tampubolon \\ hotnertampubolon@yahoo.com \\ Kamaluddin \\ kamaluddin_disdik@yahoo.com
}

\begin{abstract}
Abstrak
Penelitian ini bertujuan untuk mengetahui masalah-masalah yang dihadapi oleh para pimpinan sekolah, terutama kepala sekolah dari Satuan Pendidikan Kerjasama (SPK) dalam menegakkan Manajemen Berbasis Sekolah (MBS) di satuan pendidikan yang dipimpinnya. Penelitian ini juga bertujuan untuk mengidentifikasi strategi-strategi yang diterapkan oleh Kepala Sekolah Satuan Pendidikan Kerjasama dalam mengatasi dan menangani masalah atau hambatan yang terjadi. Metode deskriptif dengan pendekatan kualitatif pada setting yang natural atau alami, digunakan untuk melakukan penelitian ini selama 5 bulan di Sekolah Cita Buana yang berlokasi di Jakarta Selatan. Data penelitian yang dihasilkan mengidentifikasi strategi-strategi kepemimipinan yang demokratis dan profesional Kepala Sekolah dalam menegakkan Manajemen Berbasis Sekolah dalam area Pengembangan Kurikulum, Ketenagakerjaan, Kesiswaan, dan Sarana-Prasarana. Implikasi dari penelitian ini adalah tuntutan bagi Kepala Sekolah untuk mampu mengendalikan situasi internal dan eksternal dari satuan pendidikan yang dipimpinnya agar otonomi, sinergi, serta keunikan atau signature dari sekolah dapat dijaga dengan baik, serta standar dan aturan dari Diknas Pendidikan atau Pemerintah dapat juga terpenuhi.
\end{abstract}

Kata Kunci: kepala sekolah, strategi, manajemen berbasis sekolah, satuan pendidikan kerjasama 


\section{A. PENDAhuluan}

Satuan Pendidikan Kerjasama (SPK) adalah kategori sekolah yang dicetuskan oleh pemerintah sebagai pengganti kategori Sekolah Nasional Plus dan Sekolah Internasional. Berdasarkan Permendikbud No:31 Tahun 2014, dinyatakan bahwa semua sekolah yang menyelenggarakan pendidikan di Indonesia yang menggunakan kurikulum asing dan memperkerjakan guru asing harus mempunyai ijin operasional sebagai Satuan Pendidikan Kerjasama (SPK). Pada tanggal 24 Januari 2017, sekolah-sekolah yang masuk dalam kategori SPK dari seluruh Indonesia secara resmi bergabung dalam wadah yang lebih resmi, yaitu Perkumpulan Sekolah SPK Indonesia (PSSI).

Bergabungnya sekolah-sekolah SPK tersebut berangkat dari persamaan masalah yang dihadapi para Kepala Sekolah dalam mengatur sekolah masing-masing sebagai sekolah SPK. Dalam perjalanannya kepala sekolah SPK mengalami berbagai kendala terutama dalam memutar laju operasional sekolahnya. Salah satu kondisi tersebut adalah pengaturan kondisi internal dan juga eksternal satuan pendidikan yang dipimpinnya, terutama berkenaan dengan jalannya Manajemen Berbasis Sekolah sebagai SPK. Kondisi ini diperparah dengan tidak tersosialisasikannya segala peraturan mengenai Satuan Pendidikan Kerjasama (SPK) dengan jelas, baik di tingkat gugus, wilayah, maupun provinsi.

Sebagai Kepala Sekolah, pimpinan sekolah SPK tentunya harus menjalankan peran-perannya dengan cerdas, baik sesuai dengan yang digariskan dalam 5 Standar Kompetensi Kepala Sekolah, menurut PerMenDikNas No: 13 Tahun 2007, maupun peran-peran lain yang dituntut oleh yayasan pendidikan dimana sekolah SPK tersebut bernaung. Secara umum, seorang Kepala Sekolah SPK, harus memiliki strategi yang efektif untuk menjalankan keduanya dengan baik demi tegaknya Manajemen Berbasis Sekolah (MBS) yang seharusnya dipegang teguh oleh setiap penyelenggara pendidikan.

Strategi-strategi yang baik harus dimiliki oleh Kepala Sekolah SPK demi tetap berlangsungnya usaha pendidikan yang tetap berpegang pada visi dan misi sekolah, serta tujuan-tujuan pendidikan di sekolah masing-masing yang sudah menjadi signature atau keunikan dari masing-masing SPK tersebut. Pada kenyataannya, setiap SPK mempunyai tanggung-jawab yang sama dalam mengembangkan semua area dalam manajemen pendidikan di satuan pendidikannya tersebut.

Bertolak pada permasalahan dan kerumitan yang dialami oleh Kepala Sekolah selaku pimpinan Satuan Pendidikan Kerjasama (SPK) selama 4 tahun lebih berlakunya peraturan mengenai SPK tersebut, penulis tergerak untuk melakukan penelitian untuk mengumpulkan data-data masalah yang dihadapi oleh Kepala 
Sekolah-Kepala Sekolah di lingkungan Sekolah Cita Buana di Jakarta Selatan dan akhirnya menyusun suatu strategi yang pada akhirnya dapat membantu para Kepala Sekolah tersebut dan juga para pimpinan sekolah dari Satuan Pendidikan Kerjasama (SPK) lainnya dalam menjalankan roda operasional di sekolah masing-masing dengan tetap berpegang teguh pada visi-misi, dan pengembangan Manajemen Berbasis Sekolah di satuan pendidikan masing-masing.

\section{B. Temuan Penelitian dan Pembahasan}

\section{Tujuan Penelitian}

Tujuan penelitian ini diharapkan mampu memberikan gambaran yang nyata tentang masalah-masalah yang dihadapi kepala sekolah SPK dan memberikan kontribusi secara praktis mengenai strategi-strategi yang tepat dalam pengelolaan Satuan Pendidikan Kerjasama demi tegaknya Manajemen Berbasis Sekolah di satuan pendidikan yang dipimpin.

Bagi Yayasan Penyelenggara Pendidikan, hasil penelitian ini dapat digunakan sebagai salah satu acuan dalam menentukan standar yang solid untuk pemberian arahan peran dan otoritas bagi para Kepala Sekolah di lingkungan Sekolah Cita Buana. Hal ini penting demi keberhasilan penegakkan MBS di Sekolah Cita Buana itu sendiri.

\section{Metodologi}

Jenis dan desain penelitian yang digunakan adalah penelitian kualitatif (qualitative research methods) yang merangkum cakupan luas penelitian dan cenderung tidak mengubah keadaan alami tempat data akan dikumpulkan (Drew, Hardman, Hosp, 2017: 30). Validitas atau keakuratan akan berdasarkan informasi yang dikumpulkan dari berbagai sumber melalui proses triangulasi. Dalam proses triangulasi ini peneliti akan mendapatkan deskripsi masalah tertentu dari dua jenissumber berbeda, dan juga melihat bagaimana masalah tersebut diatur dalam undang-undang atau peraturan yang berlaku. Dalam hal ini pengumpulan data dilakukan melalui:

a. Wawancara dengan melibatkan berbagai responden dengan sudut pandang berbeda.

b. Observasi yang dilakukan dalam penelitian ini adalah observasi partisipan. Observasi partisipan berarti peneliti benar-benar terlibat ke latar atau kegiatan yang sedang diamati.

c. Peninjauan dokumen yang sudah ada dalam bentuk arsip sekolah dalam kaitannya dengan SPK dan MBS.

\section{Temuan Penelitian}

\section{a. Deskripsi Data}

Untuk mengetahui bagaimana MBS dijalankan di Sekolah Cita Buana sebagai Satuan Pendidikan Kerjasama, penulis mewawancarai personelpersonel yang mempunyai peranan penting dalam penegakkan manajemen pendidikan di Sekolah Cita Buana. Selain Kepala Sekolah dan Head of Department, penulis juga mewawancarai Wakil Kepala Sekolah dan juga Manajer maupun Koordinator yang terkait. 


\section{Table 1: Transkrip Hasil Wawancara}

\begin{tabular}{|c|c|}
\hline \multicolumn{2}{|c|}{$\begin{array}{l}\text { Informan: Kepsek, HOD, VP, Managers, Koordinator di Sekolah Cita Buana, Jakarta Selatan } \\
\text { Tanggal Wawancara: } 10 \text { Oktober 2018, } 20 \text { September 2018, } 19 \text { Oktober 2018, } 22 \text { Oktober 2018, } 23 \text { Oktober 2018, } 16 \\
\text { November 2019, } 9 \text { November } 2019 .\end{array}$} \\
\hline $\begin{array}{l}\text { Apa yang Anda ketahui } \\
\text { tentangMBS? }\end{array}$ & $\begin{array}{l}\text { Sebetulnya yang saya ketahui tentang manajemen berbasis sekolah adalah suatu model yang } \\
\text { pengolahanya, memberikan otonomi kepada kita atau kewenangan atau tanggung jawab yang } \\
\text { lebih besar kepada sekolah diberikan kepada kepala sekolah sehingga memberikan fleksibilitas } \\
\text { dan keluwesan kepada kita untuk mendorong partisipasi secara langsung warga sekolah, baik } \\
\text { itu guru, siswa, kepala sekolah, dan staff dan juga orang tua siswa, juga tokoh masyarakat. Dan } \\
\text { ini digunakan untuk meningkatkan mutu sekolah berdasarkan kebijakan peraturan nasional, dan } \\
\text { perundang-undangan yang berlaku. Sehingga yang mau saya tekankan dengan adanya otonomi } \\
\text { nasional serta peraturan perundang-ungan yang berlaku sekolah diberikan kewenangan dan } \\
\text { tanggung jawab untuk mengambil keputusan sesuai dengan kebutuhan, jadi tidak serta merta } \\
\text { harus mengikuti dengan peraturan pemerintah yang yang diberikan. }\end{array}$ \\
\hline $\begin{array}{l}\text { Apa yang menjadi cakupan } \\
\text { pengembangan MBS di area } \\
\text { kurikulum dan proses } \\
\text { pengajaran? }\end{array}$ & $\begin{array}{l}\text { Sebenarnya tidak hanya untuk sekolah Cita Buana saja, tetapi saya percaya setiap sekolah } \\
\text { memiliki visi misi yang berbeda, dan pastinya juga punya profil siswa yang akan dihasilkan } \\
\text { juga. Karena tergantung dari pasar sekolah tersebut. Visi misi serta profil siswa tersebutlah } \\
\text { yang akan menentukan punya partisipasi masyarakat, karena masyarakatlah yang akan } \\
\text { menentukan seperti apa kurikulum itu diterapkan. Awalnya trial and error juga, tetapi memang } \\
\text { segala sesuatunya ada yang pertama. Jatuh bangun itu biasa, tetapi kalo kita tidak pernah } \\
\text { berusaha kita tidak akan bisa. Jadi memang semakin sering terasah semakin baik. Evaluasi } \\
\text { pembelajaran, kalau melihat hasil kemampuan siswa Cita Buana dengan standar yang } \\
\text { ditetapkan pemerintah. Sebenarnya tidak melenceng jauh, kecuali kalau memang ingin sama } \\
\text { persis dengan apa yang diinginkan oleh pemerintah. Tapi kalau tetap dalam koridor yang } \\
\text { digariskan pemerintah kita mengikuti, dan disesuaikan dengan keadaan siswa. Yang jelas } \\
\text { sebagai SPK harus ada kurikulum asing, karena itukan Satuan Pendidikan Kerjasama. Dalam } \\
\text { hal ini standar yang digunakan itu untuk SD adalah IPC (International Primary Curriculum) } \\
\text { tetapi kita tetap juga mengimplementasikan kurikulum nasional, karena harus tahu menurut } \\
\text { standar negara kesatuan republik Indonesia siswa ini ada dimana. }\end{array}$ \\
\hline $\begin{array}{l}\text { Kendala-Kendala apa } \\
\text { sajakah yang dialami dalam } \\
\text { pengembangan MBS di area } \\
\text { kurikulum dan pengajaran? }\end{array}$ & $\begin{array}{l}\text { Kendalanya selama ini lebih kepada aturan. Aturan yang kurang jelas dari pemerintah, } \\
\text { terkadang juga orang yang mengukur sekolah kita ini dan juga pikiranya kurang terbuka. } \\
\text { Maunya apa yang ada dikepala meraka tanpa mau melihat sudut pandang yang lain. Lebih } \\
\text { kepada bagaimana kita menjelaskan kepada mereka, apa yang mereka mau. Sebenarnya ada } \\
\text { namun dalam bentuk yang berbeda. }\end{array}$ \\
\hline $\begin{array}{l}\text { Strategi-Strategi apa yang } \\
\text { digunakan untuk menghadapi } \\
\text { kendala-kendala tersebut dan } \\
\text { mencapai otonomi di area } \\
\text { kurikulum dan pengajaran? }\end{array}$ & $\begin{array}{l}\text { Kalau menurut saya setiap otonomi harus tetap dilaksanakan kami sebagai kepala sekolah } \\
\text { mempunyai ruang gerak. Karena kita diberikan otonomi jadi kita bebas, namun tetap pada yang } \\
\text { digariskan dalam undang-undang dan tidak meninggalkan keunikan-keunikan sekolah itu } \\
\text { sendiri, keunikan dan keunggulan menjadi highlight. Bagaimana kita menjadi manajemen } \\
\text { berbasis sekolah yang cukup baik. Dan tetap menjalin kerjama sama dengan dinas Pendidikan } \\
\text { karena anak-anak kita masih mengikuti ujian nasional yang mana ujian nasional masih dibawah } \\
\text { diknas gimana kementrian masih mengontrol SPK itu sendiri agar tetap berjalan dengan lancar } \\
\text { dan menjadi yang baik. }\end{array}$ \\
\hline $\begin{array}{lr}\text { Bagaimana } & \text { pengembangan } \\
\text { MBS } & \text { di } \quad \text { area } \\
\text { ketenagakerjaan? }\end{array}$ & $\begin{array}{l}\text { Saya rasa cukup berjalan dengan baik, karena kita juga diberikan kebebasan full untuk me- } \\
\text { manage, untuk mengelola staff dan karyawan termasuk guru-guru Cita Buana yang tentu itu } \\
\text { juga kita Bersama-sama bekerjasam dengan para Kepala Sekolahnya, jadi memang kita }\end{array}$ \\
\hline
\end{tabular}


Volume 9, Nomor 1, Januari 2020

\begin{tabular}{|c|c|}
\hline & $\begin{array}{l}\text { menggunakan strategi yang istilahnya sudah berkaloborasi antara pihak akademik dengan non- } \\
\text { akademiknya sehingga saya rasa itu cukup berjalan cukup baik ya di Cita Buana. }\end{array}$ \\
\hline $\begin{array}{l}\text { Kendala-Kendala apa } \\
\text { sajakah yang dialami dalam } \\
\text { penegakkan MBS di area } \\
\text { ketenagakerjaan? }\end{array}$ & 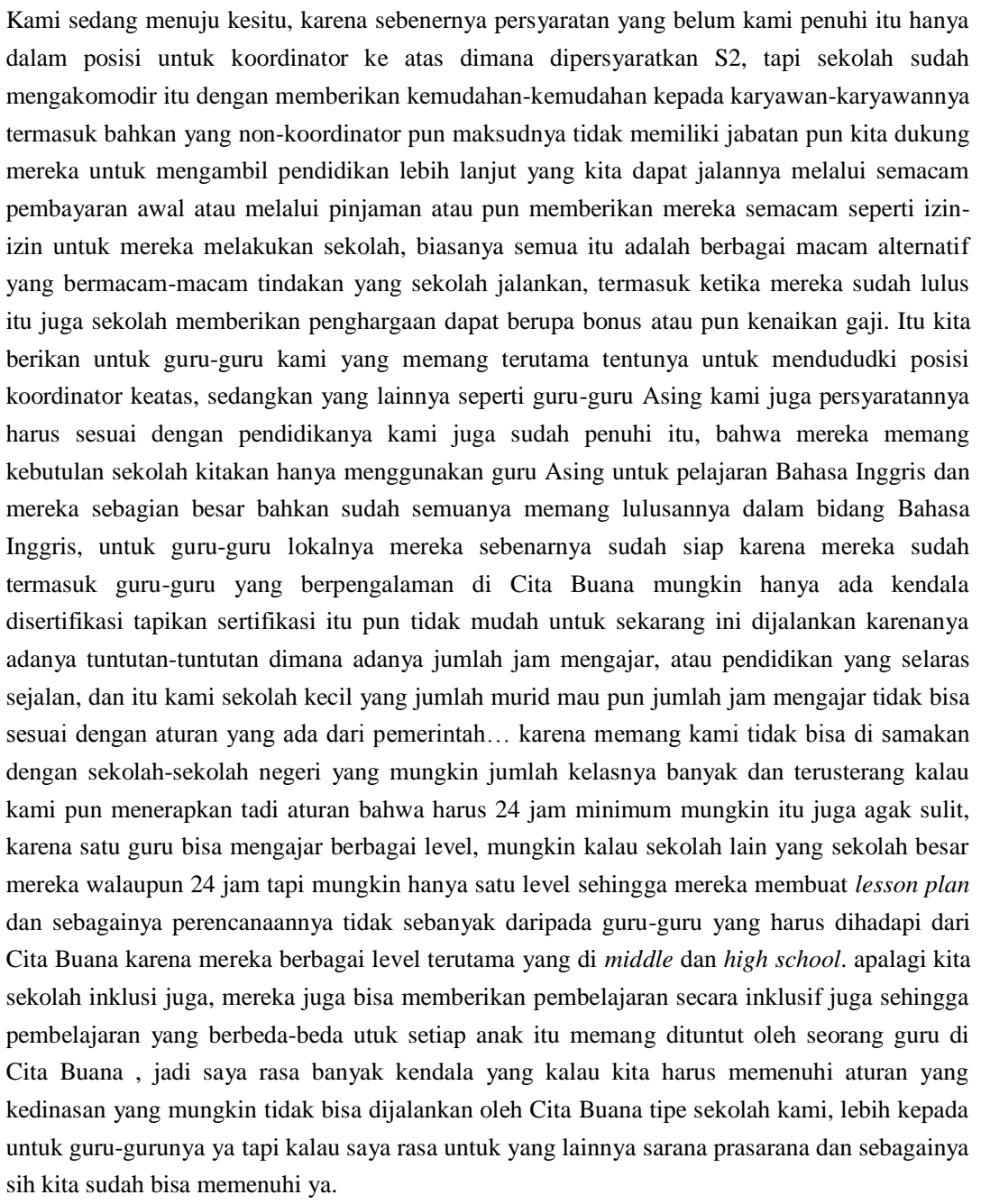 \\
\hline $\begin{array}{l}\text { Strategi-Strategi apa yang } \\
\text { digunakan untuk menghadapi } \\
\text { kendala-kendala tersebut dan } \\
\text { mencapai otonomi di area } \\
\text { ketenagakerjaan? }\end{array}$ & $\begin{array}{l}\text { kita juga diberikan kebebasan fulluntuk me-manage, untuk mengelola staff dan karyawan } \\
\text { termasuk guru-guru Cita Buana yang tentu itu juga kita bersama-sama bekerjasama dengan para } \\
\text { Kepala Sekolahnya, jadi memang kita menggunakan strategi yang istilahnya sudah } \\
\text { berkaloborasi antara pihak akademik dengan non-akademiknya sehingga saya rasa itu cukup } \\
\text { berjalan cukup baik ya di Cita Buana. }\end{array}$ \\
\hline $\begin{array}{l}\text { Bagaimana pengembangan } \\
\text { MBS di area kesiswaan? }\end{array}$ & $\begin{array}{l}\text { Yang saya ketahui tentang Manajemen Berbasis Sekolah itu seperti suatu pengaturan atau } \\
\text { aturan yang ditetapkan oleh pemerintah, diberikan kepada sekolah untuk mengurus segala hal } \\
\text { disuatu sekolah itu untuk mecapai target. Atau pemerintah memberikan kebebasan kepada } \\
\text { sekolah, tetapi harus berdasarkan pada aturan pemerintah. Kebetulan karena kita diberikan } \\
\text { kebebasan oleh pemerintah, jadi memang di Sekolah Cita Buana ini mengatur sendiri } \\
\text { segalanya, dan itu juga tidak hanya sembarangan pilih segala kegiatan kesiswaan ini juga selalu } \\
\text { pada acuan. Acuan kita yaitu tujuan pembelajaran kita apa, tujuan dari kegiatan yang diadakan } \\
\text { apa. Dengan tidak menghilangkan potensi-potensi yang ada didalam siswa yang ada di sekolah }\end{array}$ \\
\hline
\end{tabular}




\begin{tabular}{|c|c|}
\hline & $\begin{array}{l}\text { Cita Buana ini. Dan juga dapat membatu siswa secara softskills, lifeskills, maupun akademik. } \\
\text { Kegiatan yang kita miliki di sekolah Cita Buana ini cukup beragam, kita mempunya kegiatan di } \\
\text { bidang seni, olahraga, bahkan kita juga punya di bidang agama, dan ini semua sudah melalui } \\
\text { proses seleksi. Jadi kita juga melihat berdasarkan kebutuhan anak. Hal ini juga kita tawarkan } \\
\text { kepada siswa sebagai alat pengembangan potensi mereka. Jadi mereka tidak hanya mengikuti } \\
\text { kegiatan-kegiatan yang sudah kita adakan, tetapi kita juga melihat adanya seperti kemungkinan } \\
\text { siswa untuk mengembangkan potensi melalui seperti turnamen, kompetisi. Dan kita akan } \\
\text { mengirimkan kepada mereka dan menawarkanya untuk mengikutinya. Sehingga mereka sendiri } \\
\text { merasa bisa untuk mengembangkan potensi yang ada didiri mereka. }\end{array}$ \\
\hline $\begin{array}{l}\text { Kendala-Kendala } \\
\text { sajakah yang dialami dalam } \\
\text { penegakkan MBS di area } \\
\text { kesiswaan? }\end{array}$ & $\begin{array}{l}\text { Terus terang memang kita belum begitu aktif untuk mengikuti kegiatan-kegiatan yang di } \\
\text { tawarkan oleh pemerintah sendiri, karena kadang kala waktunya kurang bertepatan. Disaat } \\
\text { waktu penyelenggaraan itu kebetulan selalu berbenturan dengan kegiatan yang diadakan oleh } \\
\text { sekolah Cita Buana sendiri. Jadi belum maksimal peran serta kita juga di kegiatan yang } \\
\text { ditawarkan oleh pemerintah, selain itu juga jenis kegiatanya juga kadang kala belum tepat } \\
\text { sasaran juga dengan kondisi siswa dan sekolah. } \\
\text {...kemudian keadaan dan kondisi siswa di Cita Buana itu beragam, jadi harus ditinjau secara } \\
\text { fisik, kemampuan intelektual, kemampuan sosial ekonomi, minat dan sebagainya. Lalu } \\
\text { biasanya siswa termotivasi belajar jika mereka menyenangi apa yang mereka pelajari, padahal } \\
\text { kita harus memberikan semua pelajaran. Kemudian pengembangan potensi siswa tidak hanya } \\
\text { menyangkut ranah kognitif namun juga afektif secara psikomotorik. Jadi guru harus tau tentang } \\
\text { hal itu. }\end{array}$ \\
\hline $\begin{array}{l}\text { Bagaimana pengembangan } \\
\text { MBS di area sarana dan } \\
\text { prasaran? }\end{array}$ & $\begin{array}{l}\text { Yang saya tahu tentang MBS adalah suatu sistem kerjasama yang ada di sekolah untuk } \\
\text { mengatur jalannya sekolah tersebut. Cakupannya sih cukup luas ya karena ini terkait dengan } \\
\text { kerjasamanya antara guru, tim pendidikan dengan tim management dalam artian ini adalah } \\
\text { operasonal seperti admin, finance, terus support staff dengan guru. Jadi cukup luas cakupannya. } \\
\text { Disini termasuk dengan Board ya karena Board juga secara ga langsung in charged untuk } \\
\text { melaksanakan jalannya sekolah SCB ini. }\end{array}$ \\
\hline $\begin{array}{l}\text { Kendala-Kendala apa } \\
\text { sajakah yang dialami dalam } \\
\text { penegakkan MBS di area } \\
\text { sarana dan prasarana? }\end{array}$ & $\begin{array}{l}\text { Kendala-kendalanya yaa yang lebih sering komunikasi ya, karena kadang para guru dengan } \\
\text { Sarpras ini yang mengatur atau operasional ini suka ga sama waktunya, terus yang kedua juga } \\
\text { kadang pengertian-pengertian masing-masing departmen misalkan, guru dengan support staff } \\
\text { yang seharusnnya dikerjakannya bebarengan tapi kadang sendiri-sendiri jalannya, seperti itu. } \\
\text { Kalau untuk otonomi sendiri sebenarnya ada beberapa sudah ditentukan oleh pemerintah, } \\
\text { semisal untuk STP harus ada izin, terus untuk sumur dalam bor harus ada izin. Nah itu salah } \\
\text { satunya yang berhubungan dengan pemerintah, tapi kalau untuk yang otonomi sendiri adalah } \\
\text { kayak misalkan kayak sekolah tidak harus ada syarat-syarat lapangan basket dengan ukuran } \\
\text { segini yang ditentukan oleh pemerintah, atau misalkan sekolah tidak boleh punya lapangan } \\
\text { parkir, nah yang kayak gitu-gitukan otonomi dari sekolah itu sendiri. }\end{array}$ \\
\hline
\end{tabular}

\section{b. Pengolahan Data}

Dari data yang diperoleh, pengolahannya dilakukan berdasarkan ruang lingkup manajemen pendidikan diSekolah Cita Buanayang juga merupakan ruang lingkup dan bidang kajian Manajemen Pendidikan, yaitu:
1. Manajemen Kurikulum dan Proses Pengajaran.
2. Manajemen Ketenagakerjaan.
3. Manajemen Kesiswaan. 


\section{Manajemen Sarana dan Prasarana.}

Kemudian dari setiap ruang lingkup dan bidang kajian tersebut dilakukan pencatatan secara kronologis bagaimana masing-masing area dikembangkan, kendala-kendala apa saja yang dihadapi dan strategistrategi apa saja yang digunakan untuk mengatasi kendala yang ada.

Untuk pengembangan di setiap area atau ruang lingkup manajemen pendidikan, data yang diperoleh dari hasil wawancara kemudian digabungkan dengan data-data yang sudah diseleksi dari dokumendokumen terkait.

\section{Gambar 1: Siklus Penelitian}

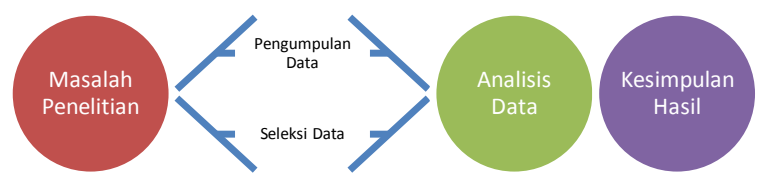

\section{c. Temuan Penelitian}

1. Manajemen Kurikulum dan Proses Pengajaran.

Konsep pengembangan kurikulum dan proses pengajaran di Sekolah Cita Buana merupakan sebuah inovasi yang menjadi keunikan atau keunggulan sekolah yang ditawarkan kepada masyarakat. Dalam hal ini Kepala Sekolah menjalankan fungsi dan perannya sebagai educator, manager, administrator, supervisor, leader, innovator, dan motivator (Mulyasa 2007:98).

Meskipun konsep pengembangan kurikulum dirasa sudah dilakukan dengan sebaik-baiknya sesuai dengan kebutuhan/ keunikan sekolah, serta mengacu kepada standar dan aturan baik dari LPA maupun ketentuan dari pemerintah, ternyata di lapangan ada banyak kendala yang harus dihadapi. Kendala-kendala tersebut dapat dirangkum sebagai berikut:

$>$ Belum tersosialisasikannya dengan baik mengenai konsep SPK kepada Dinas terkait, sehingga sering terjadi instrumen supervisi kurikulum tidak terlalu sesuai dengan perangkat kurikulum yang ada dikembangkan di sekolah.

$>$ Koordinasi dan pembinaan yang masih tumpang-tindih antara Dinas Wilayah dan Dinas Kementerian, sehingga sering kali ada perbedaan tuntutan yang harus dipenuhi terlebih berkenaan dengan evaluasi tahap akhir di jenjang tertinggi.

$>$ Pemerintah masih belum begitu mengenal kurikulum-kurikulum internasional yang dikembangkan di SCB, sehingga sering kali perlakuan disamakan dengan dengan sekolah SPK lain yang banyak 
menggunakan kurikulum dari LPA seperti Cambridge atau International Bachelorette.

Dalam rangka mensosialisasikan keberadaan Satuan Pendidikan Kerjasama (SPK) di kalangan Dinas Pendidikan, terutama di tingkat wilayah, sangat penting untuk menunjukkan partisipasi sekolah dalam komunitas sekolah di wilayah tersebut. Sekolah Cita Buana selalu mengikuti dinamika yang terjadi di wilayah meskipun tidak selalu mengikuti semua agendanya. Kepala Sekolah memilah secara seksama kegiatan mana yang sebaiknya dihadiri oleh Kepala Sekolah, kegiatan mana yang bisa didelegasikan kepada Wakil Kepala Sekolah, Koodinator, Guru, bahkan Tenaga Administrasi.

Sikap dan pemikiran terbuka selalu dikedepankan dalam kaitannya dengan sinergi dengan komunitas pendidikan di wilayah. Misalnya kegiatan Bimtek Kurikulum 2013, di Sekolah Cita Buana semua guru diikutsertakan supaya semua memahami apa yang menjadi standar pendidikan nasional di Indonesia. Meskipun Sekolah Cita Buana mengaplikasikan kurikulum internasional dan wajib memenuhi semua persyaratan dari LPA namun tidak ada salahnya Sekolah Cita Buana sebagai SPK untuk selalu memetakan materimateri yang dapat dipetakan disesuaikan dengan situasi dan kondisi sekolah. Hal ini terutama berlaku untuk materi-materi yang terkait dalam mata pelajaran yang diujikan dalam Ujian Nasional karena Sekolah Cita Buana selalu mendukung penuh siswa-siswanya untuk mengikuti Ujian Nasional, bahkan untuk siswa warga Negara asing sekalipun.

Berkenaan dengan mengusahakan dikenalnya kurikulum yang dipakai di Sekolah Cita Buana oleh pemerintah, dijabarkan pentingnya peran Kepala Sekolah untuk selalu menjaga hubungan dan komunikasi dengan Dinas Pendidikan terkait. Secara berkala atau sesuai undangan, Kepala Sekolah, Wakil Kepala Sekolah, Koordinator, dan bahkan Guru Sekolah Cita Buana hadir dalam pertemuan-pertemuan yang membahas tentang kurikulum. Bahkan diusahakan agar personil-personil tersebut untuk menjadi pembicara atau pemimpin pelatihan.

2. Manajemen Ketenagakerjaan

Dalam status Sekolah Cita Buana sebagai SPK, HRM mempunyai tanggung-jawab yang fundamental dalam pengurusan tenaga kerja asing yang bekerja sebagai pengajar di Sekolah Cita Buana. Dijelaskan bahwa perizinan tenaga kerja asing inilah yang menjadi salah satu persyaratan yang harus dipenuhi sekolah-sekolah dalam kapasitasnya sebagai SPK. Hal lain yang juga tidak kalah pentingnya adalah tugas dan tanggung jawab HRM di Sekolah Cita Buana dalam membantu tim akademik, 
dalam hal ini Kepala Sekolah dan Head of Department didalam mengurus legalitas ataupun perizinan sekolah.

Secara internal permasalahan-permasalahan yang ada dirasa sangat umum dihadapi oleh sekolah-sekolah yang lain. Biasanya masalahmasalah yang ada kemudian dijadikan sebagai program pembinaan di Sekolah Cita Buana.

Secara eksternal dalam kaitan dengan tugas dan tanggung jawab HRM dalam pengurusan ketenagakerjaan dan perizinan justru terdapat beberapa kendala yang membutuhkan tenaga dan pikiran dalam menghadapinya. Dijabarkan bahwa untuk memperoleh izin sebagai SPK yang diselenggarakan oleh yayasan pendidikan, Sekolah Cita Buana yang harus berubah status dari Sekolah Nasional Plus menjadi SPK kemudian melengkapi beberapa persyaratan yang diberikan oleh kementerian pendidikan.

Jika digambarkan, alur perizinan SPK yang diselenggarakan oleh Sekolah Cita Buana adalah sebagai berikut:

\section{Gambar 2: Alur Perizinan SPK}

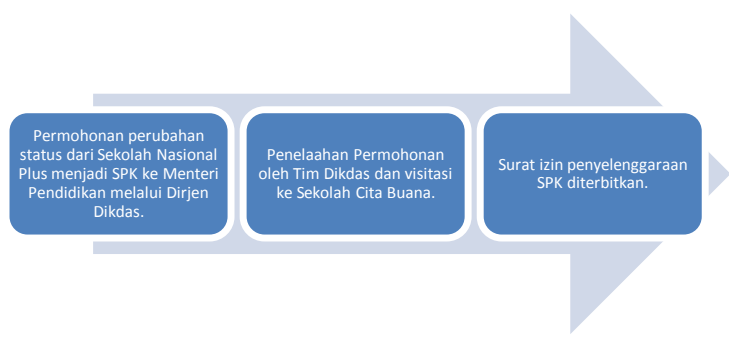

3. Manajemen Kesiswaan.

Dalam menjalankan tugasnya yang berkenaan dengan kesiswaan, Kepala Sekolah di Sekolah Cita Buana juga bekerjasama dengan Manajer Kegiatan Kesiswaanyang berkedudukan sejajar pada struktur organisasi sekolah. Tugas utama Manajer Kesiswaan adalah membantu Kepala Sekolah dalam mengatur dan memonitor kegiatan-kegiatan kesiswaan, termasuk di dalamnya kegiatan ekstrakurikuler dan events sekolah yang diadakan selama 1 tahun akademik. Adapun cakupan tanggung-jawab manajerial di bidang kesiswaan yang dilakukan untuk mengembangkan potensi peserta didik antara lain:

1. Kegiatan Ekstrakurikuler

2. Layanan Bimbingan dan Konseling

3. Pengembangan Diri dalam bidang:

$>$ Keilmuan dan Keterampilan
$>$ Kesenian
$>$ Olahraga

Secara internal menurut Kepala Sekolah, masalah yang sering dihadapi cukup beragam, sesuai dengan kondisi dan situasi di masing-masing unit atau departemen. Misalnya untuk unit TK, SD, dan Special Education masalah lebih kepada bagaimana mengajak orang tua untuk selalu 
mendukung pengembangan manajemen kesiswaan dalam aspek-aspek, seperti: kepatuhan terhadap regulasi, baik yang menyangkut pengaturan kegiatan maupun pembiayaan.

Hal lainnya adalah bagaimana menyamakan persepsi, visi, serta misi dalam mengembangkan potensi siswa. Untuk unit SMP dan SMA, lebih kepada bagaimana menumbuhkan motivasi siswa untuk berperan aktif dalam pengembangan manajemen kesiswaan di Sekolah Cita Buana sehingga mereka mampu untuk berperan sebagai subyek dalam hal ini.

Secara eksternal, peraturan- peraturan yang masih berubah-ubah sering juga dihadapi terutama yang berhubungan siswa inklusi, siswa berkebutuhan khusus, dan pendaftaran Ujian Nasional. Hal lain yang sering dialami adalah waktu yang tidak sesuai serta jenis kegiatan yang berbeda sering kali menjadi kendala bagi siswa-siswa Sekolah Cita Buana untuk dapat secara begitu aktif untuk mengikuti kegiatankegiatan yang ditawarkan oleh pemerintah.

Manajemen kesiswaan di Sekolah Cita Buana dilaksanakan mulai dari hulu ke hilir. Yang dimaksud di sini adalah manajemen kesiswaan di Sekolah Cita Buana itu meliputi seluruh proses kegiatan yang direncanakan dan dilakukan, serta dibina secara terus menerus; yaitu mulai dari siswa masuk, mengikuti proses belajar, kemudian sampai dengan kelulusannya. Dalam hal ini siswa diperlakukan sebagai subyek bukan obyek. Keadaan dan kondisi siswa yang beragam juga terus ditinjau secara keseluruhan, baik fisik, kemampuan intelektual, kemampuan sosial ekonomi, serta juga minat dan potensinya.

Hal yang selalu dijaga dalam manajemen kesiswaan di Sekolah Cita Buana adalah sinergi yang produktif antara Kepala Sekolah, Manajer Kegiatan Kesiswaan, siswa itu sendiri, dan juga orang tua siswa. Sangat penting orang tua untuk memahami bagaimana siswa akan dibimbing dari awal masuk sampai dengan kelulusannya. Selain itu disampaikan bahwa sangat penting bagi Sekolah Cita Buana untuk selalu membuat masyarakat mengerti apa yang menjadi keunikan atau signature dari pengembangan pendidikan siswa. Signature tersebut kemudian selalu diolah dan dikembangkan sehingga benar-benar menjadi hal yang membedakan Sekolah Cita Buana dengan SPK yang lain.

\section{Manajemen Sarana dan Prasarana}

Kebutuhan dan pengembangan sarana dan Prasarana di Sekolah Cita Buana, dilaksanakan oleh Koordinator Bidang Sarana dan Prasarana bekerjasama dengan Kepala Sekolah dan Head of Department. Disampaikan bahwa sarana dan prasarana walalupun bukan yang terpenting, namun bisa dikatakan sangat menunjang untuk keberhasilan proses pembelajaran di Sekolah Cita Buana. Kualitas pembelajaran bisa meningkat dengan dukungan sarana dan prasarana memadai. Di samping itu proses pembelajaran akan dapat dirasakan lebih efektif dengan adanya fasilitas atau benda-benda pendukung pembelajaran. 
Rencana pengembangan sarana dan prasarana di Sekolah Cita Buana, termasuk proses-proses yang harus dilalui harus dilakukan secara mandiri oleh sekolah. Yayasan Penyelenggara Pendidikanbertanggung jawab juga untuk lancarnya penyediaan sarana dan prasarana yang dibutuhkan.

Disampaikan juga bahwa sejauh ini ketersediaan dan kondisi Sarana dan Prasarana di Sekolah Cita Buana sudah sesuai dengan standar yang ditetapkan oleh pemerintah. Sebagai contoh bahwa pada saat visitasi atau monitoring dari Diknas Pendidikan baik dari tingkat wilayah maupun kementerian, banyak hal sudah cukup memenuhi bahkan melebihi poin-poin yang terdapat dalam instrumen monitoring atau evaluasi yang diberikan.

Adapun kendala-kendala yang dihadapi dalam pengembangan dan pemberdayaan sarana dan prasarana di sekolah, menurut Koordinator Sarana Prasarana lebih kepada penjadwalan, komunikasi, dan perencanaan yang dilakukan oleh semua unit atau departemen di Sekolah Cita Buana.

Secara eksternal, aturan-aturan umum dari pemerintah mengenai standar ukuran bangunan tertentu dan sarana air bersih, diakui sebisa mungkin dijalankan dan diakomodir meskipun tidak mudah mengingat kondisi dan kebutuhan sekolah yang tidak sama.

\section{d. Pembahasan Temuan Penelitian}

1. Temuan Penelitian di Area Manajemen Kurikulum dan Proses Pengajaran.

Otonomi luas diberikan kepada Kepala Sekolah terlebih dalam mengatur dan mengembangkan kurikulum dan pengajaran di Sekolah Cita Buana. Melalui kerjasama dengan Wakil Kepala Sekolah Bidang Kurikulum Nasional dan Internasional, Kepala Sekolah menghasilkan suatu konsep pendidikan kolaborasi dan integrasi antara Muatan Indonesia (MI), dalam hal ini Kurikulum Nasional 2013 dan Standar Pendidikan International (SPI), dalam hal ini standar yang ditetapkan oleh:

$>$ IEYC (International Early Years Curriculum)

$>$ IPC (International Primary Curriculum)

$>$ IMYC (International middle Years Curriculum)

$>$ ACT (Australian Capital Territory Curriculum)

Didalam pengaturan dan pengaplikasian program pembelajaran, Kepala Sekolah bersama timnya merancang suatu pengembangan kurikulum yang diselaraskan dengan standar pendidikan yang ditetapkan pemerintah dan tertuang juga dalam rencana strategis sekolah. 
Strategi yang digunakan oleh para pimpinan sekolah di Sekolah Cita Buana adalah strategi yang dikemukakan oleh Tony Bush dan Marianne Coleman (2000:16), yaitu membagi strategi dalam dua aspek penting, yaitu:

a. Bidang Cakupan

Kepala Sekolah mempunyai gambaran keseluruhan tentang Sekolah Cita Buana. Pimpinan Sekolah dalam fungsinya sebagai manajer telah berupaya untuk mengintegrasikan tugastugasnya dan mendelegasikan jika perlu. Oleh karena itu mereka terus konsisten dengan nilai-nilai sekolah, dan nilainilai tersebut haruslah sesuai dengan kondisi sekolah dan lingkungan sekitarnya.

b. Jadwal Waktu

Strategi memerlukan skala waktu yang cukup luas. Manajemen jangka panjang ini tidak hanya merespon peristiwa-peristiwa penting. Secara khusus strategi ini memerlukan suatu periode waktu tertentu dan kemudian direfleksikan ke dalam perencanaan pengembangan sekolah. Dalam konteks Sekolah Cita Buana adalah perencanaan pengembangan sekolah melalui kegiatan-kegiatan yang diselenggarakan oleh Diknas Pendidikan dalam upayanya semakin mengenalkan nama sekolah dan karakteristiknya.

2. Temuan Penelitian di Area Manajemen Ketenagakerjaan.

Di dalam mengatur ketenagakerjaan, Kepala Sekolah Cita Buanabekerjasama dengan manajer non-akademik, yang disebut HRM (Human Resource Manager). Manajer ini mempunyai kedudukan yang sejajar dalam struktur organisasi di Sekolah Cita Buana serta mempunyai jabaran tugas dan tanggung jawab tersediri yang diberikan oleh yayasan penyelenggara pendidikan. HRM bekerjasama dengan Kepala Sekolah sebagai manajer akademik dalam pengaturan dan pengembangan tenaga pendidik dan kependidikan, sesuai dengan aturan-aturan yang ditetapkan oleh yayasan penyelenggara pendidikan, maupun aturan-aturan yang ditetapkan oleh perundang-undangan ketenagakerjaan di Indonesia.

Didalammenyeselaikan hal-hal yang terjadi secara internal dan dengan otonomi yang diberikan, Kepala Sekolah dan Head of Department bekerjasama dengan HRM melakukan strategi-strategi pengembangan ketenagakerjaan dalam area- areaStaffing, Performance Evaluation, Compensation,Professional Development, Safety and Health.

Secara eksternal, didalam mengatasi kendala yang ada dan dalam usaha terus menegakkan otonomi namun tetap mengikuti dinamika yang ada, HRM senantiasa berusaha memperoleh instrumen-instrumen yang berhubungan dengan kepegawaian dari pemerintah. Hal ini dirasa sangat penting sebagai evaluasi, misalnya dalam hal penerimaan pegawai apakah sudah berjalan dengan benar dan sesuai dengan aturan 
Depnaker yang terbaru. Kerjasama dan sinergi yang baik dengan Kepala Sekolah dan Pimpinan Departemen lain sangat juga dibutuhkan supaya saling bertukar informasi demi suksesnya manajemen ketenagakerjaan di Sekolah Cita Buana. Di sinilah salah satu karakteristik berhasilnya MBS, yaitu teamwork yang kompak dan transparan (Mulyasa, 2007:35).

3. Temuan Penelitian di Area Manajemen Kesiswaan.

Strategi atau pendekatan yang dilakukan oleh Kepala Sekolah dalam menjalankan manajemen di area kesiswaan termasuk dalam arti dan fungsi Kepala Sekolah sebagai pemimpin yang mengupayakan hal-hal baik (Michael Fullan 2001: 10), termasuk di antaranya:

1. Pengembangan prestasi siswa.

2. Penumbuhan semangat belajar dan motivasi siswa untuk terikat pada proses pembelajaran.

3. Peningkatan peran serta orang tua dan anggota masyarakat.

4. Pemeliharaan kepuasan dan antusiasme stake-holders untuk terus bergerak maju.

Dalam menjalankan hal-hal di atas, Kepala Sekolah menekankan pentingnya selalu berusaha mengikuti alur yang digariskan pemerintah dalam manajemen kesiswaan namun juga tetap pro-aktif memberikan masukan dan solusi kepada Dinas Pendidikan terkait sehingga otonomi sekolah tetap bisa dijalankan. Diingatkan juga bahwa MBS itu adalah suatu sistem yang memberikan otonomi atau kesempatan sekolah untuk mengembangkan apa yang menjadi ciri khasnya atau local wisdom yang dimiliki. Tentu sesuai dengan pakem-pakem yang sudah diarahkan pemerintah, tetapi pada saat yang bersamaan sekolah juga bertanggung-jawab menjalankan kewenangannya untuk menjadi lebih mandiri sehingga bisa mengembangkan potensi-potensinya termasuk siswa-siswanya.

4. Temuan Penelitian di Area Manajemen Sarana Prasarana.

Area belajar untuk siswa yang lebih luas, kantin yang lebih luas, serta gedung serbaguna yang lebih besar dirasakan sudah sangat mendesak. Seperti yang diakui juga oleh Kepala Sekolah bahwa proses perencanaan penambahan sarana tersebut dirasa cukup lambat. Penjadwalan dan perencanaan yang dilakukan sejak dini, menurut para Kepala Sekolah dan Head of Department sudah semaksimal mungkin dilakukan. Begitu juga dengan koordinasi dan komunikasi antar departemen yang sudah sering dilakukan. Pada kenyataan kondisi ini disebut oleh Kepala Sekolah sangat tricky, artinya membutuh kecerdikan tersendiri untuk mengatur dan menyiasatinya. Dalam hal ini Kepala Sekolah memaksimalkan kemampuannya sesuai dengan kebutuhan, yaitu harus mampu berperan sebagai leader, innovator, dan motivator di sekolahnya (Mulyasa, 2007: 98). 


\section{Kesimpulan}

MBS di Sekolah Cita Buana dipahami sebagai suatu strategi atau pendekatan dalam usaha sekolah untuk menjadi otonom atau mandiri dalam mengembangkan manajemen pendidikannya dengan tetap menjaga keunikan yang ada.

Dalam mengatur area-area manajemen pendidikan, Kepala Sekolah mengembangkan strategi kepemimpinan yang demokratis dan profesional dimana dalam beberapa area manajemen pendidikan di Sekolah Cita Buana, seperti ketenagakerjaan, kesiswaan, dan sarana-prasarana, Kepala Sekolah bersinergi dengan Manager dari masing-masing area dan bekerja secara profesional. Kenyataan bahwa otoritas yang tidak sepenuh pada area manajemen kurikulum dan proses pengajaran, Kepala Sekolah mempunyai tanggung jawab lain dalam menjalankan manajemen ketenagakerjaan, kesiswaan, dan saranaprasarana dengan kesimpulan sebagai berikut:

1. Penegakkan MBS dalam Area Kurikulum dan Proses Pengajaran

Area kurikulum dan proses pengajaran merupakan area penegakkan manajemen pendidikan dimana Kepala Sekolah Cita Buana mempunyai otoritas sangat penuh. Dalam penegakkan area kurikulum dan proses pengajaran Kepala Sekolah Cita Buana menggunakan semua fungsi EMASLIM nya, yaitu sebagai educator, manager, administrator, supervisor, leader, innovator, dan motivator.

2. Penegakkan MBS dalam Area Ketenagakerjaan

Dalam manajemen ketenagakerjaan, Kepala Sekolah mengoptimalkan fungsi educator nya untuk meningkatkan profesionalisme tenaga kependidikan di sekolahnya, menciptakan iklim sekolah yang kondusif, memberikan dorongan kepada seluruh tenaga kependidikan, serta mengaplikasikan konsep pembelajaran yang menjadi keunikan sekolah.

3. Penegakkan MBS dalam Area Kesiswaan

Untuk area kesiswaan, Kepala Sekolah berbagi tugas dan tanggungjawab dengan Manajer Kesiswaan dengan mengoptimalkan fungsi planning atau perencanaannya. Hal ini dikarenakan Manajer kesiswaan lebih berperan secara tekhnis dalam pengembangan potensi siswa terutama pada bidang nonakademik, sehingga dalam fungsi ini Kepala Sekolah lebih kepada memetakan dengan cermat bagaimana meraih suatu tujuan secara holistik. Kepala Sekolah merencanakan langkah-langkah yang akan ditempuh untuk mencapai tujuan tersebut. Seperti contohnya menentukan prosedur penerimaan siswa baru, mengidentifikasi masalah siswa, dan pendampingan siswa sampai menyelesaikan studinya.

4. Penegakkan MBS dalam Area Sarana dan Prasarana

Selanjutnya pada area manajemen sarana dan prasarana, dengan adanya Koordinator Bidang Sarana dan Prasarana yang menangani segala sesuatunya dan langsung melapor kepada Yayasan Penyelenggara Pendidikan, maka Kepala Sekolah lebih mengoptimalkan fungsinya sebagai motivator.Pada area ini Kepala Sekolah menggunakan strateginya untuk memberikan motivasi kepada para tenaga kependidikan dalam melakukan berbagai tugas dan 
fungsinya dalam kondisi yang terbatas. Motivasi ini dapat ditumbuhkan melalui pengaturan lingkungan fisik, pengaturan suasana kerja, disiplin, dorongan, penghargaan secara efektif, dan penyediaan berbagai sumber belajar melalui inovasi dan kreativitas yang ada.

\section{DAFTAR PUSTAKA}

ACT. 2004. ACT Department of Education and Training, http://www.australiancurriculum.edu.au

BPS. 2016. Daftar Sekolah di Provinsi DKI Jakarta, http://www2.pdsp.kemedikbud.go.id

Dr. E. Mulyasa, M.Pd. 2006. Manajemen Berbasis Sekolah. Gramedia Capri Anjaya. 2017. Sekolah Lokal Berkualitas Internasional. PSSDM

Tonny Bush \& Marianne Coleman. 2006. Leadership and Strategic Management in Education. IRCiSoD

Ellen A.Benowitz, M. Ed. 2001. Principles of Management. Wiley Publishing, Inc. Michael Fullan. 2014. Leading in a Culture of Change. Jossey - Bass

Agustinus Bendur. 2008. A Study of the Implementation of School-Based Management in Flores Primary Schools in Indonesia. The University of Newcastle, Australia.

BSNP. 2017. Badan Standar Nasional Pendidikan, http://bsnp-indonesia.org/

Dinas Pendidikan DKI Jakarta. 2017. Data dan Informasi Pendidikan, https://disdik.jakarta.go.id/

ANPS. 2015. The Association of National and Private Schools, https://anps-bi.org/

Wahjosumidjo. 2002. Kepemimpinan Kepala Sekolah. Rajawali Press.

Nurkolis, MM. 2009. Manajemen Berbasis Sekolah. Grasindo.

Sarjono. 2009. Implementasi Manajemen Berbasis Sekolah dalam Rangka Peningkatan Prestasi Sekolah. Universitas Sebelas Maret, Surakarta.

Clifford J. Drew, Michael L. Hardman, John L. Hosp. 2017. Designing and Conducting Research in Education. SAGE.

Dr. Drs. I Wayan Suwendra, S.Pd, M.Pd. 2018. Metodologi Penelitian Kualitatif. Nilacakra.

John W. Best, James V. Kahn. 1998. Research in Education. Pearson, India. 